\title{
Correction to: Comparative transcriptome analyses define genes and gene modules differing between two Populus genotypes with contrasting stem growth rates
}

\author{
Xiao Han ${ }^{1,3}$, Yi An ${ }^{2,3}$, Yangyan Zhou ${ }^{3}$, Chao Liu ${ }^{3}$, Weilun Yin ${ }^{3^{*}}$ and Xinli Xia ${ }^{3^{*}}$ (C)
}

\section{Correction to: Biotechnol Biofuels (2020) 13:139} https://doi.org/10.1186/s13068-020-01758-0

Following publication of the original article [1], the authors would like to correct the funding statement. The correct number for the National Key Program on Transgenic Research is 2018ZX08020002. The number was changed from 2018ZX08021001 to 2018ZX08020002 during the project approval process. This has been corrected with this erratum.

The original article [1] has been updated.

\begin{abstract}
Author details
${ }^{1}$ State Key Laboratory of Subtropical Silviculture, College of Forestry and Biotechnology, Zhejiang A\&F University, Lin'an, Hangzhou 311300, China. ${ }^{2}$ Sino-Australia Plant Cell Wall Research Centre, State Key Laboratory of Subtropical Silviculture, College of Forestry and Biotechnology, Zhejiang A\&F University, Lin'an, Hangzhou 311300, China. ${ }^{3}$ Beijing Advanced Innovation Center for Tree Breeding by Molecular Design, National Engineering Laboratory for Tree Breeding, College of Biological Sciences and Technology, Beijing Forestry University, Beijing 100083, China.
\end{abstract}

Published online: 17 March 2021

\section{Reference}

1. Han X, An Y, Zhou Y, Liu C, Yin W, Xia X. Comparative transcriptome analyses define genes and gene modules differing between two Populus genotypes with contrasting stem growth rates. Biotechnol Biofuels. 2020;13:139. https://doi.org/10.1186/s13068-020-01758-0.

\section{Publisher's Note}

Springer Nature remains neutral with regard to jurisdictional claims in published maps and institutional affiliations.

Full list of author information is available at the end of the article

(c) The Author(s) 2021. This article is licensed under a Creative Commons Attribution 4.0 International License, which permits use, sharing, adaptation, distribution and reproduction in any medium or format, as long as you give appropriate credit to the original author(s) and the source, provide a link to the Creative Commons licence, and indicate if changes were made. The images or other third party material in this article are included in the article's Creative Commons licence, unless indicated otherwise in a credit line to the material. If material is not included in the article's Creative Commons licence and your intended use is not permitted by statutory regulation or exceeds the permitted use, you will need to obtain permission directly from the copyright holder. To view a copy of this licence, visit http://creativeco mmons.org/licenses/by/4.0/. The Creative Commons Public Domain Dedication waiver (http://creativecommons.org/publicdomain/ zero/1.0/) applies to the data made available in this article, unless otherwise stated in a credit line to the data. 